\title{
REDUCTION OF ORGANIC POLLUTANTS FROM WATER TREATMENT PLANTS USING WASTES OF ALUM INDUSTRY
}

\author{
Ahmed A. Mohamed ${ }^{(1)}$; Wael S. I. Abou Elmagd ${ }^{(2)}$ \\ and Hanan S. Ibrahim (3)
}

1) Chemistry and Environment Specialist, Quality Control and Environmental Affairs Department, Holding Company for Water and Wastewater 2) Chemistry Department, Faculty of Science, Ain Shams University 3) Water Pollution Research Department, National Research Center

\begin{abstract}
Various organic compounds increase in surface water due to the agricultural drains located, the industrial effluents of industrial activities, fish farming cages and random domestic drainage. First, a survey analysis was carried out for five different water treatment plants (WTPs) in Greater Cairo. Coagulation, flocculation and sedimentation were carried as a technique for the removal of total organic carbon (TOC) concentration. Coagulation has been carried out using alum dose between $27-32 \mathrm{~g} / \mathrm{m}^{3}$ with average removal percent of (TOC) $(16 \%-41 \%)$, In this study, De-Aluminated Kaolin (DAK)-a waste by-product from alum production-in various dosages between $0.5 \mathrm{~g}-4 \mathrm{~g}$ were added and an average removal percent of (TOC) $(45.7 \%-77.1 \%)$ at contact time of 15 minutes has been found to achieve the maximum (TOC) removal at concentrations of (TOC) $(6.6 \mathrm{mg} / \mathrm{l})$ and $\mathrm{pH}$ equal 8.3 .
\end{abstract}

Keywords: Organic matter; alum; Water Treatment Plants; Total organic carbon (TOC); De-Aluminated Kaolin (DAK).

\section{INTRODUCTION}

There is a growing concern about wide spread contamination of surface with various organic compounds due to the agricultural drainage water, industrial 
effluents and domestic sewage which all contain highest concentration of Total organic carbon (TOC)(Abdelhalim et al., 2014).

There are many methods suggested for the removal of organic compounds from aqueous solutions. These methods have been classified in two principal categories: destructive processes such as destructive oxidation with ozone, hydrogen peroxide, or manganese oxide and recuperative processes such as adsorption into porous solids, membrane separation, ion exchange and solvent extraction (Uddin et al., 2007).

The reduction of the organic content in raw water by different methods including: activated carbon (Symons et al., 1981) and oxidation (using either ozone or chlorine dioxide as the oxidant), for the degradation of the organic matter to reduce the trihalomethanes THMs formation potential of the raw water (Glaze et al., 1987 and George et al., 2008).

De-aluminated kaolin (DAK) is a waste by-product of aluminum extraction from kaolin by sulfuric acid. (DAK) can be obtained after acid leaching process of kaolin, the acid-leaching process gave a yield of $47.35 \pm 1.64 \%$ of alum using raw kaolin (Mostafa et. al, 2001), the remaining kaolin is called de-aluminated kaolin is used as adsorbent material for ammonia (Mawla et al., 2016).

In this study de-aluminated kaolin (DAK) which used as adsorbent material for the removal of total organic carbon (TOC), the addition of (DAK) will be applied before the pre-chlorination in order to reduce the organic load in the source water to avoid the formation of carcinogenic disinfection by-products (DBPs). 


\section{MATERIALS AND METHODS}

1 Survey analysis for TOC: A survey study was carried out to determine the concentrations of (TOC) in raw and treated waters from five WTPs in Greater Cairo revealed the most polluted sites. Analysis was done according to (APHA, 2012).

The selected WTPs were (El-Tebben, El-Fustat, Mostorod, Embaba, and Gezeret El-Dahab) the total quantity produced as drinking water by these WTPs in sum is about 3,700,000 m3/day.

Total organic carbon (TOC) were analyzed with a (TOC) analyzer (Sievers5310) method adopted from APHA $5310 \mathrm{C}$ and optimized for the laboratory conditions.

2 Treatment process description: The treatment process in the five mentioned WTPs is almost the same in sequence and techniques. It began by mechanical screening for blocking large objects, followed by primary disinfection for inactivation of pathogens by using chlorine gas, and then the optimum dose of aluminum sulfate coagulant is added to remove particulates and reduce the organic load, than, the water is subjected to rapid sand filters to remove the rest of the turbidity. In final step post-disinfection is applied to assure residual chlorine in the produced water that protects it against any further pollution in the distribution networks.

3 Reduction of (TOC): In this section of the study, the effect of de-aluminated kaolin (DAK) adsorbent material for (TOC) was studied by applying various conditions that affect the adsorption of organic matter in raw water. 
3.1. De-Aluminated kaolin (DAK): DAK is a by-product from alum production from Aluminum Sulfate Company of Egypt in Abu zaable Qalyubiyah. (DAK) was obtained after acid leaching process of kaolin, the acid-leached process yields of aluminum sulfate using calcined kaolin, the remaining residue is called de-aluminated kaolin (DAK) were grinded into the following particle sizes $(0.08,0.125,0.2,0.315,0.4$ and $0.63 \mathrm{~mm}$ diameters $)$ to be used in this study as adsorbent material for (TOC).

3.2. Treatment methodology: Treatment procedures carried out by the following steps:

- Samples of raw water from River Nile by different concentration of (TOC).

- Dosages of 3g DAK were added to examine the (TOC) treatment efficiency.

- The stirrer was adjusted for $15 \mathrm{rpm}$ and let to stand for about 10 minutes.

- The samples were then filtered through a syringe 0.22 micro filter.

- The remaining (TOC) was then measured using (TOC) analyzer (Sievers5310).

The removal efficiency is then calculated by the following equation (1

$$
\text { Total (TOC) removal efficiency } \%=\frac{\left(C_{o}-C\right)}{C_{o}} \times 100
$$

Where $\mathrm{C}_{\mathrm{o}}=$ Total (TOC) without the action of adsorbent $(\mathrm{mg} / \mathrm{l})$

$$
\mathrm{C}=\text { Total (TOC) after using the adsorbent (mg/l) }
$$

3.2.1. Effect of particle size: Experiments were carried out on samples to determine the effect of particle size on the adsorption process. Varying particle sizes $(0.08,0.125,0.2,0.315,0.4$ and $0.63 \mathrm{~mm}$ diameters of (DAK)) were used $1000 \mathrm{ml}$ of sample of $6.6 \mathrm{mg} / \mathrm{l}$ concentrations of (TOC) was poured in $1000 \mathrm{ml}$ BEAKER with $3 \mathrm{~g}$ de-aluminated kaolin (DAK) and stirred at $15 \mathrm{rpm}$ for 15 minutes. The samples were then filtered through a syringe 0.22 micro filter. 
J. Environ. Sci.

Institute of Environmental Studies and Research - Ain Shams University

3.2.2. Effect of de-aluminated kaolin (DAK) dosage: Experiments were carried out on samples to determine the effect of adsorbent dosage on the adsorption process. Various dosages were added $(0.5,1,1.5,2,2.5,3,3.5$ and $4 \mathrm{~g}) .1000$ $\mathrm{ml}$ of sample of $6.6 \mathrm{mg} / \mathrm{l}$ concentrations of (TOC) was poured in $1000 \mathrm{ml}$ BEAKER and stirred at $15 \mathrm{rpm}$ for 15 minutes, $\mathrm{pH}$ of the sample was equal 8.3.

\subsubsection{Effect of Total organic carbon (TOC) concentration (adsorbate):} Various (TOC) concentrations were prepared $(3,3.5,4,4.5,5,5.5,6,6.5,8$, 8.5, 9 and $11 \mathrm{mg} / \mathrm{L}$ ) by applying U.S. EPA method 9060A through dissolving $(0.2128 \mathrm{~g})$ of potassium hydrogen phthalate in $100 \mathrm{ml}$ deionized water (DI) to prepare 1,000 mg/L of (TOC) stock solution (U.S.EPA, 2006).

Then the mentioned solutions were prepared through dilution from the (TOC) stock solution which poured in $1000 \mathrm{ml}$ BEAKER with $3 \mathrm{~g}$ (DAK) and stirred at $15 \mathrm{rpm}$ for 15 minutes. The initial $\mathrm{pH}$ of the sample was equal 8.3 in the natural operation range.

3.2.4. Effect of pH on (TOC) adsorption capacity: To determine the effect of $\mathrm{pH}$ on the adsorption process; $100 \mathrm{ml}$ synthetic samples in Erlenmeyer flask were adjusted with $1 \mathrm{M} \mathrm{H}_{2} \mathrm{SO}_{4}$ or $1 \mathrm{M} \mathrm{NaOH}$ to $\mathrm{pH}(2,4,6,6.5,7,7.5,8,8.5$, 10 and 12). The $\mathrm{pH}$ effect on adsorbent $3 \mathrm{~g}$ DAK activities was determined at constant (TOC) load (6.6 mg/L) and mixing speed of $15 \mathrm{rpm}$ for 15 minutes. 
3.2.5. Effect of time: The effect of contact time on removal of (TOC) was studied with various adsorbents at initial concentrations of (TOC) $(6.6 \mathrm{mg} / \mathrm{l})$ in time ranging $(5,15,25,35,45,55,65,70$ and 75 minutes) and mixing speed of $15 \mathrm{rpm}$ on adsorbent $3 \mathrm{~g}$ DAK in $100 \mathrm{ml}$ samples in nine Erlenmeyer flasks.

2.4 Removal efficiencies of (TOC): The samples were analyzed for (TOC) and the removal efficiencies were determined through equation (1).

\section{RESULTS AND DISCUSSIONS}

1 Survey analysis for TOC and THMs: As mentioned in section 2.1 a survey study carried out to determine the WTPs site having high (TOC) values and the data are presented in Figure (1).

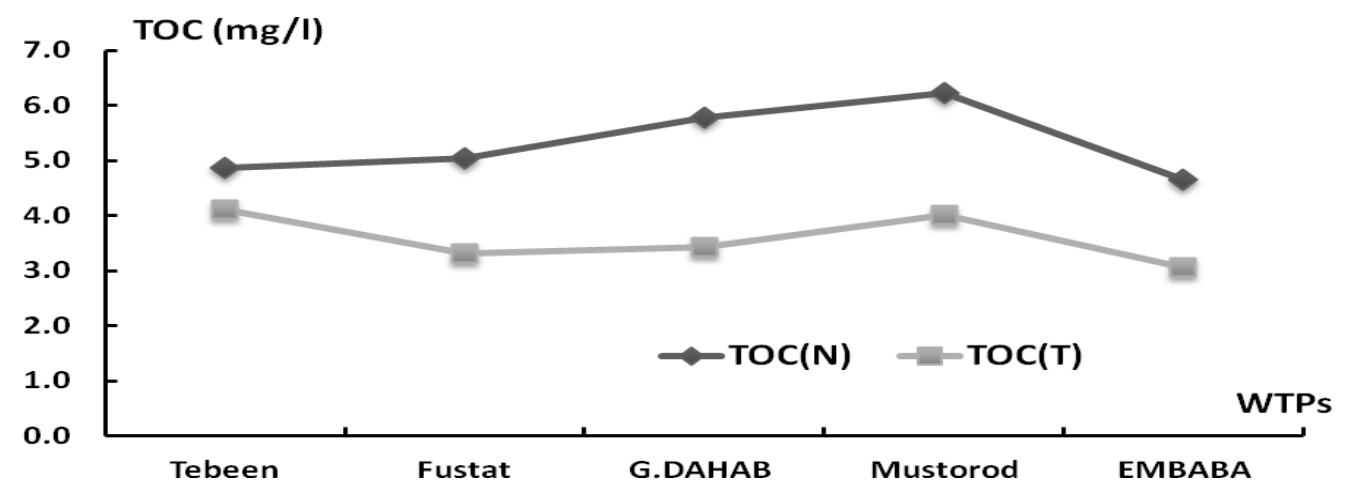

Fig. (1): Concentration of TOC (mg/l) in Greater Cairo WTPs raw water River Nile (N) - Drinking Water tap (T).

In the Egyptian regulation (TOC) has no standard limit, but (TOC) a good indicator for organic pollution. In Figure (1), the amount of organic matter TOC is maximum at Mostorod WTP with $6.63 \mathrm{mg} / \mathrm{l}$; the presence of many companies 
such as (Al Delta steel, petroleum pipelines, Cairo Petroleum) The treatment plants (WTPs) was coagulation has been carried out using alum dose between $27-32 \mathrm{~g} / \mathrm{m}^{3}$ with average removal percent of (TOC) $(16 \%-41 \%)$

\section{Removal of (TOC) using (DAK):}

\subsection{Effect (DAK) particle size on (TOC) removal:}

Batches experiments were carried out for removal of (TOC) from water sample. The effects of (DAK) particle size are shown in figure (2).

Decreasing the (DAK) particle size greatly increases the (TOC) removal to reach maximum $(68.2 \%)$ and a particle size of $0.08 \mathrm{~mm}$. This could be attributed to the surface area which increases with decreasing the (DAK) particle size (Buragohain et. al., 2013).

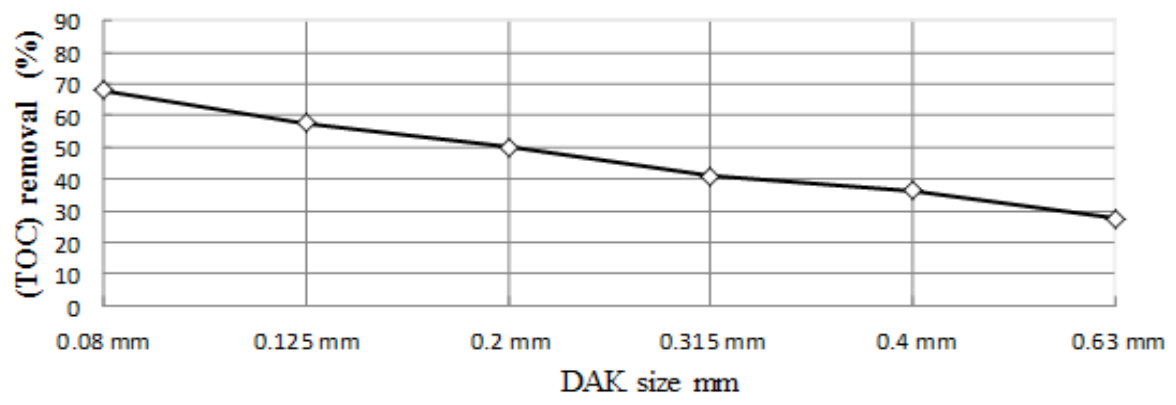

Fig. (2): Effect particle size of (DAK) in (TOC) removal percentage.

3.2.2 Dose Effect of (DAK): Batches experiments were achieved to determine the optimum (DAK) dose that will achieve the best (TOC) removal percentage. Dose the effects of (DAK) are in figure (3). 


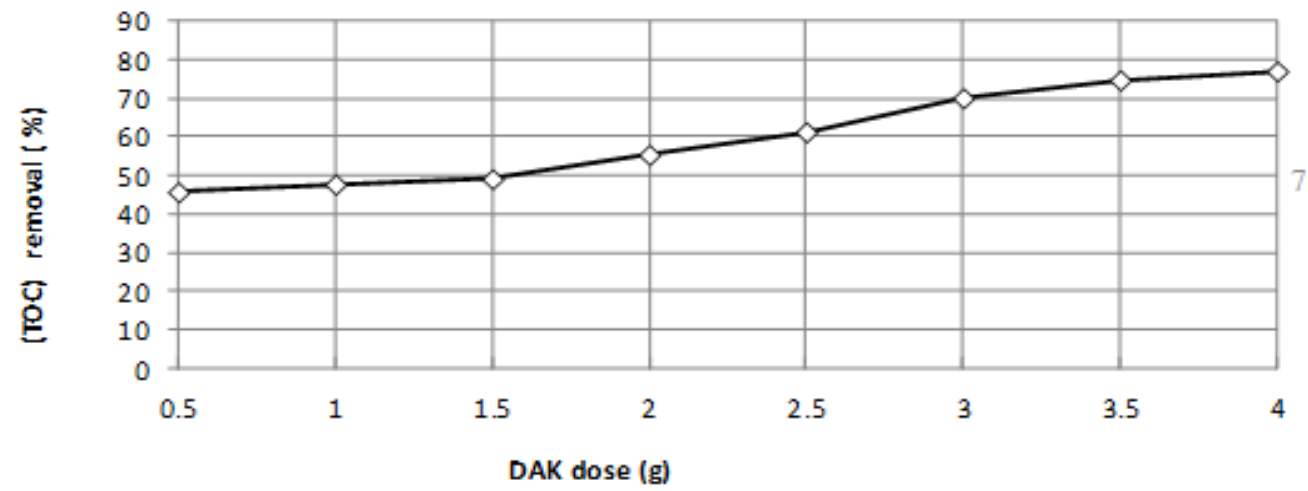

Fig. (3): Dose effect of (DAK) in (TOC) removal percentage

Increasing dose of (DAK) increases (TOC) removal percent until it reach maximum (77.1\%) using (DAK) dose of $4 \mathrm{~g}$. Increase the number of active sites by increasing (DAK) dose.

\subsubsection{Effect of (TOC) concentration on the treatment by (DAK): The effects} of the initial sample concentration on removal of (TOC) with DAK were experimented according to synthetic sample.

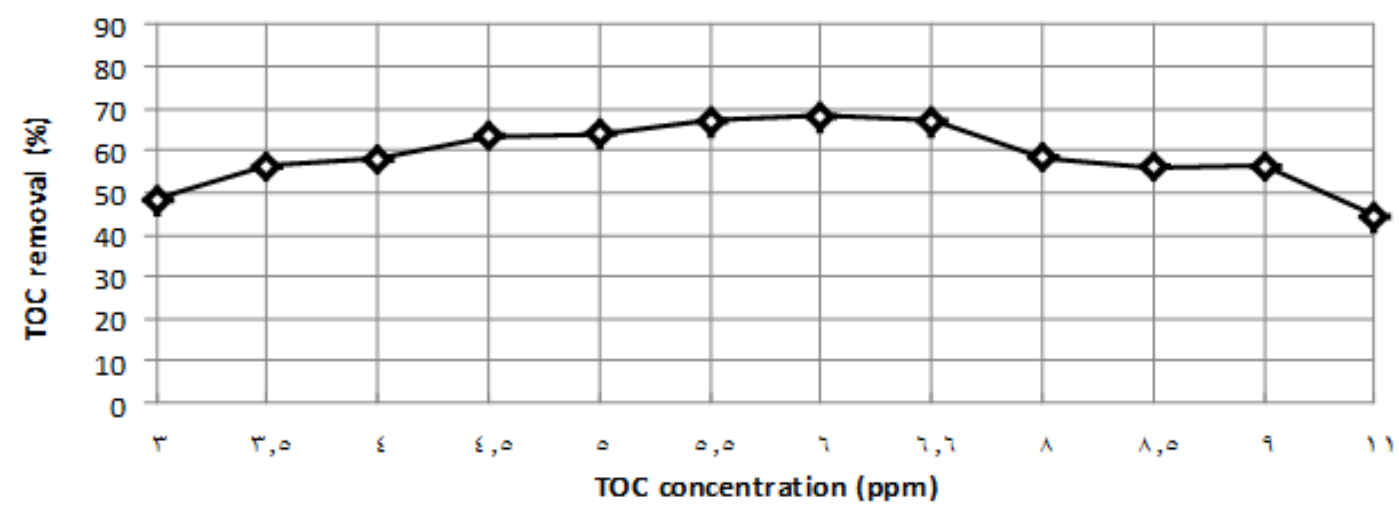

Fig. (4): Effect of initial concentration on TOC removal \% by using (DAK) 
Figure (4) displayed that high initial concentration of (TOC) increased the (TOC) removal percent until it reached maximum 68.2\% with 3 gm (DAK). This could be attributed to adsorption process is dependent on initial concentration of adsorbent which infer that the used mass of (DAK) has been saturated with the organic matter.

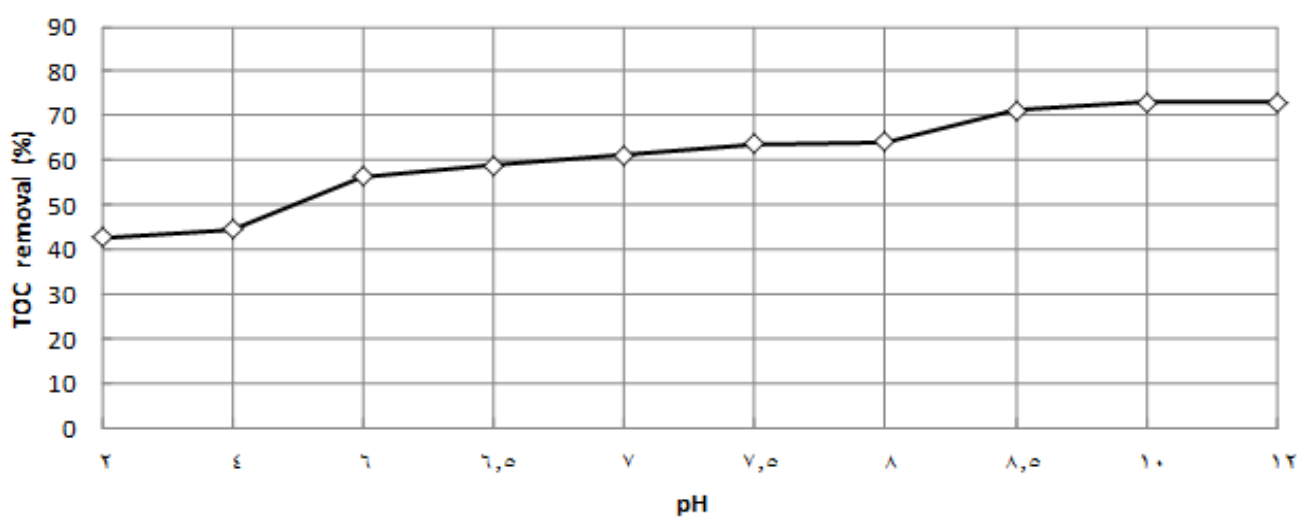

Fig. (5): Hydrogen ion concentration Effect on (TOC) removal \% by DAK.

3.2.4 Effect of pH in (TOC) removal by DAK: Results presented in figure (5), showed that the removal efficiency of (TOC) by DAK depended on $\mathrm{pH}$ values which affects on the surface charge of the adsorbent, degree of ionization, and speciation of adsorbate species. Increasing $\mathrm{pH}$ from 2 to 12 increases the (TOC) removal percent. (TOC) the removal $73 \%$ is much favorable in alkaline condition of $\mathrm{NaOH}$ caused DAK surface area increases ( Phair et al. 2014) and micro-cracks on the particles of DAK due to strong base $\mathrm{NaOH}$ concentration and be fragile (Sukmak et al. 2014). 


\subsubsection{Effect of contact time in (TOC) removal by DAK.}

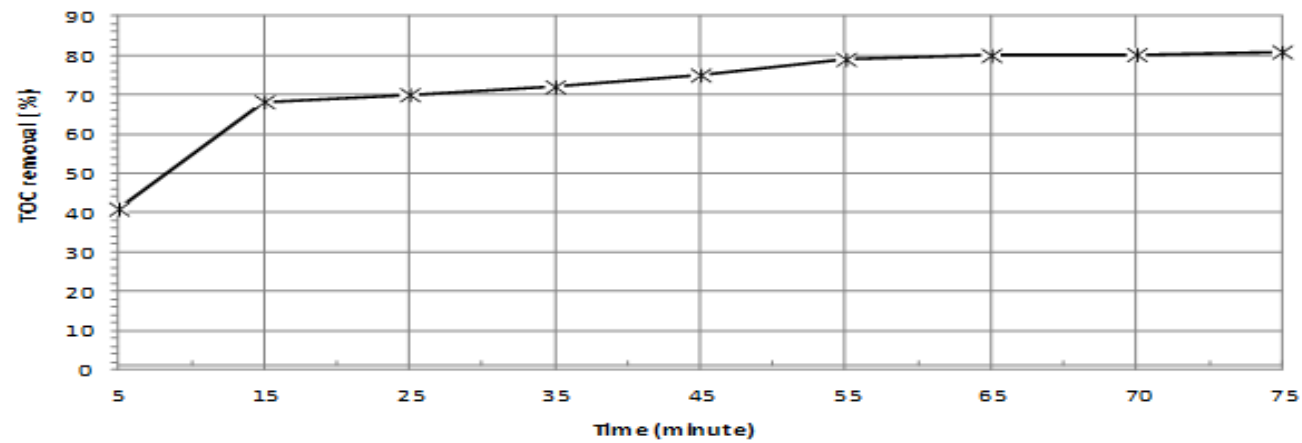

Fig. (6): Contact time Effect on (TOC) removal \% by DAK.

The above results show removal process can be considered very fast because of largest amount of (TOC) attached on surface area DAK within the first $15 \mathrm{~min}$ of experiment (68.2\% removal of (TOC)). The equilibrium time required for the adsorption of (TOC) on DAK is almost $45 \mathrm{~min}(55.1 \%)$. Low significant change in (TOC) removal was observed after 55 min. It was seen from the experimental results that the percentage removal increases with increasing of contact time till equilibrium is occur.

\section{CONCLUSION}

The survey on Cairo water treatment plants revealed that Mostorod-WTP is the most polluted spot by organic matter with TOC concentration of $6.63 \mathrm{mg} / \mathrm{l}$ for the raw water, with economical and environmental significance DAK a byproduct from alum production from Aluminum sulfate company which using dealuminated kaolin in water treatment show that DAK removed up to $60 \%$ removal of (TOC) using $3 \mathrm{~g}$ of DAK $0.08 \mathrm{~mm}$. Recommendation in study the Effect of $\mathrm{pH}$ in (TOC) removal by DAK which add $\mathrm{NaOH}$ to sample the (TOC) 
removal $73 \%$ is much favorable in alkaline condition of $\mathrm{NaOH}$ caused DAK surface area increases so we can used the modified DKA.

\section{REFERENCES}

Abdelhalim, N. H.; Imam, E. H. and Nour, M. H. (2014): Fate of Natural Organic Matter and Formation of Disinfection By-Products in a Conventional Water Treatment Plant. Proceedings of the Water Environment Federation, 2014(6), 2703-2718.

Abdelmawla M., Abdulla N. and Razek T., (2016): "Monitoring of ammonia in rosetta branch", $1^{\text {th }}$ International Conference on the Future of Energy, Geology and Environment (EGE), April 3-4, 2016.

American Public Health Association, American Water Works Association, Water Environment Federation (APHA) (2012): Standard Methods for the Examination of Water and Wastewater, Rice, E.W., Baird, R.B., Eaton, A.D. L.S. Clesceri, L.S., Eds.; 22nd ed.; American Public Health Association: Washington, D.C.

Banat, F.A., B. Al-Bashir, S. Al-Asheh and O. Hayajneh. Adsorption of Phenol by Bentonite, Environmental Pollution, 107 (2002): 391-398.

Clark, R. M. (1998): Chlorine Demand and T-THM Formation Kinetics: a Second-Order Model. Jour. Environ. Eng. ASCE, 124(1): 16-24.

EPA, (2011): The Environmental Protection Agency. Water treatment manual: disinfection .report. Johnstown Castle, Co. Wexford, Ireland. Page 187.

Farren, E. A. (2003): Reducing trihalomethane concentrations by using chloramines as a disinfectant (Doctoral dissertation, Worcester Polytechnic Institute).

Filella, M. (2009): Freshwaters: which NOM matters?. Environmental chemistry letters, 7(1), 21-35.

Ganesan, R. and Thanasekaran, K. (2011): Decolourisation of textile dyeing Wastewater by modified solar Photo-Fenton Oxidation. International Journal of Environmental Sciences, 1(6), 1168. 
George, P. A.; Thomas, P. T.; Dionysios, D. D. (2008): Chemical and microbial decontamination of pool water using activated potassium peroxymonosulfate, water research, 42, $2899-2910$.

Ghanbari, F. and Moradi, M. (2017): Application of peroxymonosulfate and its activation methods for degradation of environmental organic pollutants: Review. Chemical Engineering Journal, 310, 41-62.

Glaze, W. H.; Joon-Wun, K. and Douglas H. C. (1987): "The chemistry of water treatment processes involving ozone, hydrogen peroxide and ultraviolet radiation." 335-352.

Huang, Y.; Wang, Z.; Fang, C.; Liu, W.; Lou, X. and Liu, J (2016): Importance of reagent addition order in contaminant degradation in an Fe(II)/PMS system, RSC Adv. 6.70271-70276.)

Ksibi, M. (2006): Chemical oxidation with hydrogen peroxide for domestic wastewater treatment. Chemical Engineering Journal, 119(2), 161165 .

Kotronarou, A.; Mills, G.; Hoffmann, M. R. (1991): Ultrasonic Irradiation of pNitrophenol in Aqueous Solution. the journal of physical chemistry, 95(9), 3630.

March, J. G. and Gual, M. (2007): Breakpoint chlorination curves of grey-water. Water Environment Research : A Research Publication of the Water Environment Federation, 79(8), 828-32.

Mostafa, N. Y., El-Hemaly, S.A.S., Al-Wakeel, E. I., E-Korashy, S. A., Brown, P. W., (2001): "Characterization and Evaluation of the pozzolanic activity of Egyptian industrial by-product, I. Silica fume and dealuminated kaolin, Cem. Concr. Res. 31(3)(2001), 467-474.

Petri, B. G. ; Watts, R. J.; Teel, A. L.; Huling, S. G.; and Brown, R. A. (2011): Fundamentals of ISCO using hydrogen peroxide. In In situ chemical oxidation for groundwater remediation (pp. 33-88). Springer New York.

Phair, J. W., Van Deventer, J. S. J., \& Smith, J. D. (2004): Effect of Al source and alkali activation on $\mathrm{Pb}$ and $\mathrm{Cu}$ immobilisation in fly-ash based "geopolymers". Applied Geochemistry, 19(3), 423-434. 
Saidan, M.; Rawajfeh, K. and Fayyad, M. (2013): Investigation of factors affecting THMs formation in drinking water. American Journal of Environmental Engineering, 3(5), 207-212.

Sang, L. (2013): Chemical Decontamination of Outdoor Pool Water using Oxone ${ }^{\circledR}$ and the Impact of Nanoparticles from Personal Care Products (Doctoral dissertation, University of Cincinnati).

Singer, P. C.; Borchardt, J. H. and Colthurst, J. M. (1980): The effects of permanganate pretreatment on trihalomethane formation in drinking water. Journal (American Water Works Association), 573-578.

Symons, J. M.; Stevens, A. A.; Clark, R. M.; Geldreich, E. E.; Love, O. T. and DeMarco, J. (1981): Treatment techniques for controlling trihalomethanes in drinking water. EPA 600/2-81- 156, Final Report for U.S. EPA-DWRD, U.S. EPA, Cincinnati, OH.

Venkatadri, R. and Peters, R. W. (1993): Chemical oxidation technologies: ultraviolet light/hydrogen peroxide, Fenton's reagent, and titanium dioxide-assisted photocatalysis. Hazardous Waste and Hazardous.

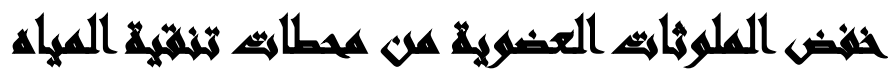

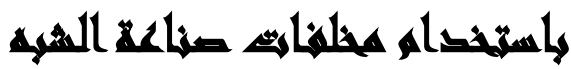

\section{[1]}

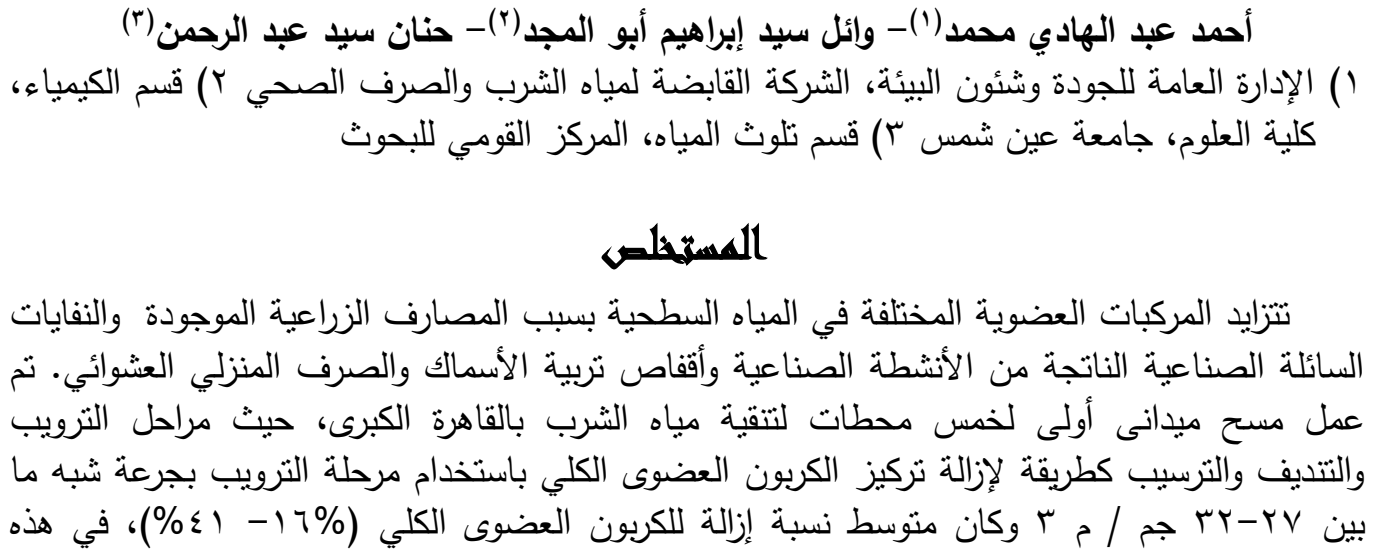


الدراسة تم استخدام الكاولين منزوع الألومنيوم جزئيًا ( كأحد المخلفات الثانوية لعملية إنتاج الثبه)

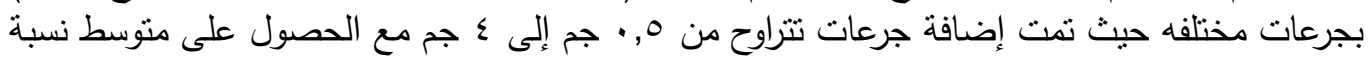

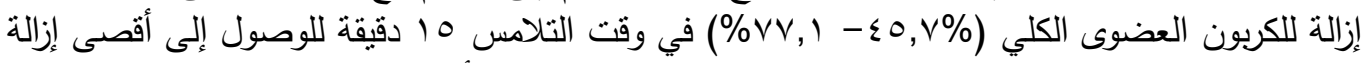

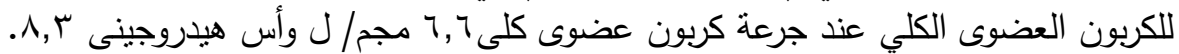

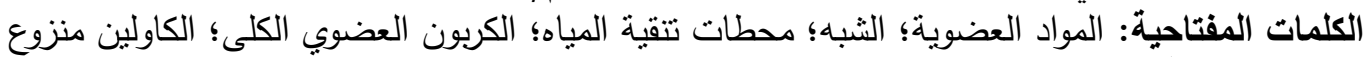
الألومنيوم جزئياً 